\title{
Identifikasi Korelasi Minat Terhadap Kemampuan Analisis Siswa pada Konsep Usaha dan Energi
}

\author{
Z. Miskiyyah ${ }^{1 *}$, W. Liliawati ${ }^{2}$, dan D. Rusdiana ${ }^{2}$ \\ ${ }^{1}$ Magister Pendidikan Fisika Fakultas Pendidikan Matematika dan Ilmu Pengetahuan \\ Alam (FPMIPA), Universitas Pendidikan Indonesia, Indonesia \\ ${ }^{2}$ Departemen Pendidikan Fisika Fakultas Pendidikan Matematika dan Ilmu Pengetahuan \\ Alam (FPMIPA), Universitas Pendidikan Indonesia, Indonesia \\ *Email: yaya_zm95@upi.edu
}

Received: October 22 $2^{\text {th }}, 2020$. Accepted: February $4^{\text {th }}, 2021$. Published: February $28^{\text {th }}, 2021$

\begin{abstract}
Abstrak
Penelitian dilakukan untuk mengidentifikasi korelasi minat terhadap kemampuan analisis siswa pada konsep usaha dan energi. Metode penelitian yang digunakan adalah kuantitatif dekriptif dengan teknik penentuan sampel purposive sampling. Sampel penelitian terdiri atas 28 orang dengan karakteristik 20 perempuan dan delapan laki-laki di MA Bandung. Instrumen yang digunakan adalah angket dan tes. Hasil penelitian menunjukkan bahwa minat siswa terhadap konsep usaha dan energi berada pada kriteria sangat tinggi sebesar $21,43 \%$ dan kriteria tinggi sebesar $78,57 \%$; sedangkan kemampuan analisis siswa berada pada kriteria rendah yakni sebesar $37 \%$ dan sangat rendah sebesar 63\%. Berdasarkan perhitungan dengan menggunakan SPSS IBM 23 didapatkan nilai Cramer V sebesar 0,000 (kurang dari 0,05) sehingga dapat disimpulkan bahwa terdapat korelasi antara minat terhadap kemampuan analisis siswa pada konsep usaha dan energi. Hasil penelitian ini menunjukkan pentingnya minat belajar siswa sebagai bekal untuk menerima pembelajaran, khususnya pada kemampuan analisis siswa. Oleh karena itu, guru diharapkan dapat menciptakan suasana belajar yang menyenangkan untuk meningkatkan minat belajar dan kemampuan analisis siswa.
\end{abstract}

\begin{abstract}
The research was conducted to identify the correlation between interest in learning towards students' analytical skills on the concept of work and energy. The research method used is
\end{abstract}


descriptive quantitative with purposive sampling technique of determining the sample. The research sample consisted of 28 people with the characteristics of 20 girls and 8 boys in Senior High School Bandung. The instruments used were questionnaires and tests. The results showed that students' interest in the concept of work and energy was at a very high criterion of $21.43 \%$ and a high criterion of $78.57 \%$. The students' analytical skills were in the low criteria of $37 \%$ and very low of $63 \%$. Based on calculations using the SPSS IBM 23, the Cramer V value was 0,000 (less than 0.05 ) so it can be concluded that there is a correlation between student interest in learning and analytical skills on the concept of work and energy. The results of this study indicate the importance of student interest in learning as a provision for receiving learning, especially in students' analytical skills. Therefore, teachers are expected to create a pleasant learning atmosphere to increase student interest in learning and analytical skills. (22021PERJ

Keywords: Analytical skills; student interest; Work \& Energy.

\section{PENDAHULUAN}

Pembelajaran di Indonesia menerapkan kurikulum 2013 revisi yang melatih empat keterampilan, yaitu: berpikir kritis dan pemecahan masalah, komunikasi, kolaborasi, serta kreativitas dan inovasi yang disebut keterampilan abad 21. Guru harus mempersiapkan siswa agar dapat mencapai keterampilan dasar dalam bekerja, yaitu keterampilan abad 21 (Barron \& Hammond, 2008). Keterampilan tersebut merupakan hal pokok yang digunakan dalam penyusunan instrumen soal PISA.

Hasil PISA 2018 menunjukkan Indonesia masih berada pada level pemahaman. Selain itu, Indonesia juga mengalami penurunan skor PISA dari 2015 sebesar 403, sedangkan tahun 2018 menjadi 396 (Tohir, 2019). Instrumen dalam soal PISA membutuhkan pemikiran tingkat tinggi. Berdasarkan hal tersebut, keterampilan berpikir tingkat tinggi (HOTS) harus dilatihkan bagi siswa Indonesia.

Keterampilan berpikir tingkat tinggi (HOTS) adalah keterampilan untuk menghubungkan, memanipulasi, mentransformasi pengetahuan dan pengalaman yang sudah dimiliki (Najihah et al., 2018). Penelitian terkait tentang perencanaan dan pelaksanaan pembelajaran fisika berbasis HOTS telah dilakukan oleh (Pratama \& Istiyono, 2015) dan menunjukkan bahwa keterampilan berpikir tingkat tinggi siswa berada pada kategori sedang. 
Pada taksonomi Bloom, keterampilan berpikir tingkat tinggi berada pada level kognitif C4, C5, dan C6 (Ariyana et al., 2018). Fokus penelitian ini adalah kemampuan dasar HOTS pada dimensi proses kognitif C4 (menganalisis). Analisis (C4) merupakan kemampuan awal yang harus dimiliki siswa sebelum mencapai tingkat ke dua dalam HOTS yaitu C5 (mengevaluasi). Kemampuan menganalisis adalah kemampuan untuk menguraikan, mengatur, dan menemukan makna tersirat (Hasan \& Jalil, 2016; Qomariya et al., 2018; Refiana et al., 2016; Suryani et al., 2015). Siswa dikatakan memiliki kemampuan analisis jika dapat memecah materi menjadi bagian-bagian kecil dan menjelaskan keterkaitan antar bagian tersebut (Qomariya et al., 2018; Winarti, 2015).

Minat belajar fisika sangat dibutuhkan demi terciptanya kegiatan belajar mengajar yang efektif untuk mencapai keterampilan analitis (Oon \& Subramaniam, 2013). Minat bersifat pribadi dan terkait erat dengan sikap. Minat masih dianggap sebagai pembangun motivasi yang penting dalam pembelajaran (Salsabila \& Setyaningrum, 2018). Minat dan kemampuan awal dapat memengaruhi prestasi belajar fisika (Astuti, 2015; Djudin, 2018). Minat siswa dapat meningkat jika pembelajaran diintegrasikan dengan hal-hal yang menarik, contohnya adalah praktikum fisika online interaktif (Gryczka et al.,
2016). Selain laboratorium fisika online interaktif, minat yang diterapkan pada model diskusi berbantuan media animasi juga dapat mempengaruhi hasil belajar siswa (Oktalia et al., 2017; Riwahyudin, 2015). Berdasarkan hasil penelitian tentang minat siswa terhadap pembelajaran yang telah dikaji tersebut, penelitian ini dilakukan untuk menguji korelasi minat siswa terhadap kemampuan analisis siswa pada konsep usaha dan energi.

Usaha dan energi merupakan materi yang harus dipelajari siswa pada pelajaran fisika di Sekolah Menengah Atas (SMA). Selain alasan tersebut, telah dilakukan penelitian tentang identifikasi kesulitan siswa SMA pada konsep usaha dan energi oleh Rahmatina, et al., (2018). Temuan dari penelitian tersebut antara lain: 1) kesulitan yang umum terjadi pada siswa yaitu pada konsep penerapan gaya, 2) siswa kesulitan dalam menggambarkan pergerakan benda jika disajikan melalui grafik penerapan teorema usaha-energi kinetik, 3) siswa salah mengartikan korelasi usaha gaya gravitasi dengan ketinggian benda di tanjakan, dan 4) siswa kesulitan dalam menggambarkan grafik korelasi energi dan ketinggian yang benar sebagai gambaran pergerakan benda dengan jalur parabola dan pengaruhnya oleh gaya eksternal dari sistem (Rahmatina, et al., 2018). Konsep usaha dan energi juga telah digunakan dalam penelitian yang 
berkaitan dengan kemampuan kognitif siswa yang di dalamnya terdapat domain proses kognitif C4 (menganalisis) (Nurazizah et al., 2017). Berdasarkan hasil wawancara dengan guru dan analisis skor hasil belajar, nilai siswa masih belum memenuhi kriteria ketuntasan minimal (KKM) sebesar 75. Studi pendahuluan juga menunjukkan bahwa skor rata-rata siswa sebesar 46.

Penelitian ini bertujuan untuk mengidentifikasi korelasi minat siswa terhadap kemampuan analisis pada konsep usaha dan energi. Penelitian ini dilakukan juga berdasarkan bahwa belum adanya yang menghubungkan minat siswa dengan kemampuan analisis siswa. Minat siswa sendiri cenderung dihubungkan dengan hasil belajar atau prestasi belajar siswa (Irawati, 2018; Riwahyudin, 2015).

\section{METODE}

Metode penelitian yang digunakan adalah deskriptif dengan pendekatan kuantitatif. Populasi dalam penelitian ini adalah seluruh siswa kelas XI IPA MA Bandung. Penentuan sampel menggunakan teknik non-probability sampling, yaitu dengan purposive sampling berdasarkan pertimbangan kondisi siswa. Sampel dipilih sebanyak 28 siswa, terdiri atas 20 siswa perempuan dan 8 siswa laki-laki yang digunakan untuk melihat pola korelasi berdasarkan gender.
Instrumen untuk mengukur minat siswa menggunakan angket. Terdapat enam aspek penilaian pada angket yang digunakan, yaitu: 1) kesiapan siswa dalam menerima pelajaran (M1), 2) kemampuan siswa dalam menjawab pertanyaan (M2), 3) antusiasme siswa dalam menjawab pertanyaan (M3), 4) perhatian siswa dalam pembelajaran (M4), 5) ketekunan siswa dalam mengerjakan soal latihan (M5), dan 6) minat siswa dalam menjawab soal (M6). Keenam aspek tersebut kemudian dikembangkan menjadi 12 item pertanyaan. Instrumen divalidasi oleh satu dosen dan 10 orang rekan penulis. Hasil uji validitas angket minat siswa disesuaikan dengan pendapat seorang ahli, kemudian direvisi menjadi 6 aspek.

Instrumen untuk mengukur kemampuan analisis siswa yang digunakan adalah tes deskripsi yang berjumlah 3 item yang terdiri dari konsep usaha, konsep energi, dan hubungan usaha dan energi. Instrumen kemampuan analisis siswa, divalidasi oleh ahli sebanyak dua orang dosen dan 10 orang rekan penulis menggunakan tes logika. Selain menggunakan tes logika, instrumen divalidasi menggunakan tes empiris kepada siswa dengan hasil soal nomor $1, \mathrm{r}_{\text {tabel }}<\mathrm{r}_{\text {hitung }}(0,284$ $<0,295)$, soal nomor $2, \mathrm{r}_{\text {tabel }}<\mathrm{r}_{\text {hitung }}$ $(0,284<0,290)$ dan butir nomor 3, $\mathrm{r}_{\text {tabel }}<\mathrm{r}_{\text {hitung }}(0,284<0,357)$ kemudian masuk dalam kategori valid. Instrumen juga telah diuji reliabilitas dengan hasil $\mathrm{r}_{\text {tabel }}<r_{\text {hitung }}$ 
$(0,284<1,05)$ reliabel. Selanjutnya soal kemampuan analisis diujikan di lapangan untuk diberikan kepada siswa yang telah mempelajari konsep usaha dan energi. Hasil (skor) kemampuan analisis siswa dianalisi menggunakan statistik yaitu phi Cramer's V. Statistik dianalisis dengan bantuan software SPSS IBM 23.

\section{HASIL DAN PEMBAHASAN}

Hasil penelitian korelasi minat siswa terhadap kemampuan analisis siswa pada konsep usaha dan energi ditinjau dari tiga aspek. Ketiga aspek tersebut yaitu: minat siswa pada konsep usaha dan energi, kemampuan analisis siswa pada konsep usaha dan energi, dan korelasi minat siswa terhadap kemampuan analisis siswa pada konsep usaha dan energi.

\section{Minat Siswa pada Konsep Usaha dan Energi}

Gambar 1 menunjukkan persentase minat siswa ditinjau dari gender. Hasil yang diperoleh pada penelitian ini sesuai dengan hasil penelitian Astuti (2015) tentang pengaruh kemampuan awal dan minat terhadap prestasi belajar fisika yang menyatakan bahwa minat belajar siswa berada pada tingkat senang. Minat siswa pada masing-masing aspek berdasarkan gender dapat dilihat pada Tabel 1.

Berdasarkan hasil analisis, minat siswa pada aspek kemampuan siswa dalam menjawab pertanyaan tergolong lebih banyak yang berada pada kategori sangat rendah. Hasil tersebut didapatkan dari cara siswa menjawab soal uraian dari instrumen keterampilan analisis. Beberapa faktor yang menyebabkan kemampuan siswa dalam menjawab pertanyaan berada pada kategori sangat rendah antara lain: 1) materi usaha dan energi kurang melekat dalam ingatan siswa, 2) tidak persiapan terlebih dahulu sebelum mengerjakan soal tes, 3) siswa cenderung sulit memahami materi usaha dan energi (Mustofa et al., 2016; Rahmatina et al., 2018; Susanti et al., 2014).

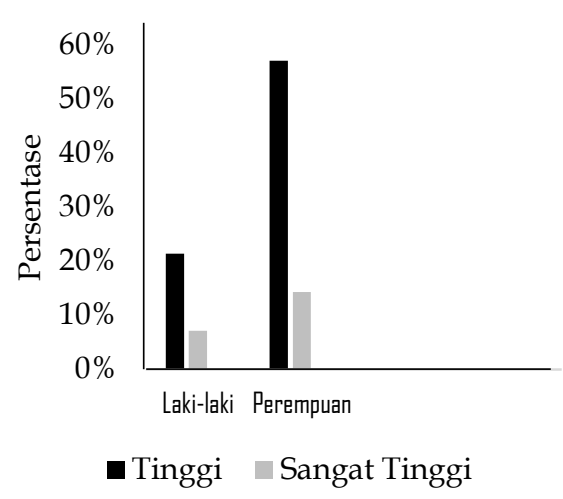

Gambar 1. Persentase Minat Siswa Berdasarkan Gender 
Tabel 1. Aspek Minat Berdasarkan Gender

\begin{tabular}{|c|c|c|c|}
\hline \multirow[t]{2}{*}{ Aspek Minat } & \multirow[t]{2}{*}{ Kategori Aspek } & \multicolumn{2}{|c|}{ Gender } \\
\hline & & Laki-laki & Perempuan \\
\hline Kesiapan siswa dalam & Sangat Tinggi & 1 & 17 \\
\hline \multirow[t]{2}{*}{ menerima pelajaran (M1) } & Tinggi & 5 & 3 \\
\hline & Rendah & 2 & \\
\hline Kemampuan siswa dalam & Tinggi & 2 & \\
\hline \multirow[t]{2}{*}{ menjawab soal (M2) } & Rendah & 2 & 2 \\
\hline & Sangat Rendah & 6 & 16 \\
\hline Antusiasme siswa dalam & Sangat Tinggi & 1 & 1 \\
\hline \multirow[t]{2}{*}{ menjawab soal (M3) } & Tinggi & 6 & 16 \\
\hline & Rendah & 1 & 3 \\
\hline Perhatian siswa dalam & Sangat Tinggi & 4 & 12 \\
\hline pembelajaran (M4) & Tinggi & 4 & 8 \\
\hline Ketekunan siswa dalam & Sangat Tinggi & 1 & 8 \\
\hline \multirow[t]{2}{*}{ mengerjakan soal latihan (M5) } & Tinggi & 6 & 12 \\
\hline & Rendah & 1 & \\
\hline Minat siswa dalam menjawab & Sangat Tinggi & & 2 \\
\hline \multirow[t]{3}{*}{ soal $(\mathrm{M} 6)$} & Tinggi & 8 & 13 \\
\hline & Rendah & & 3 \\
\hline & Sangat Rendah & & 2 \\
\hline
\end{tabular}

\begin{tabular}{|l|l|l|l|l|l|l|}
\hline No. & \multicolumn{3}{|c|}{ Pernyataan } & \multicolumn{3}{c|}{ Pilihan } \\
\cline { 3 - 7 } & $\begin{array}{l}\text { Saya antusias/semangat saat pelajaran fisika } \\
\text { berlangsung }\end{array}$ & & SS & S & TS & STS \\
\hline
\end{tabular}

Gambar 2. Contoh Instrumen Minat Siswa

\section{Kemampuan Analisis Siswa pada Konsep Usaha dan Energi}

Data tentang kemampuan analisis siswa diperoleh dari nilai siswa dalam menjawab soal. Hasil penelitian pada Gambar 3 menjelaskan persentase kemampuan analisis siswa, baik laki-laki maupun perempuan. Hasil analisis menunjukkan bahwa keterampilan analisis siswa (C4) masih berada pada persentase sangat rendah (SR), sedangkan persentase sangat tinggi (ST) tidak ada. Hal ini merupakan pembahasan yang menarik untuk diulas karena kemampuan analisis (C4) merupakan kemampuan tingkat dasar dari kategori keterampilan berpikir tingkat tinggi (Anderson et al., 2001; Jannah et al., 
2018; Novita et al., 2016; Sartono, 2017). Posisi keterampilan berpikir tingkat tinggi (HOTS) dalam dimensi proses kognitif dapat dilihat pada Gambar 4 (Ariyana et al., 2018).

Kemampuan analisis siswa adalah kemampuan dasar atau awal yang harus dimiliki siswa yang merupakan keterampilan abad 21. Contoh instrumen kemampuan analisis siswa beserta jawaban siswa terdapat pada Gambar 5. Rata-rata siswa cenderung tidak memberikan jawaban pada soal kemampuan analisis dan lebih memilih menjawab soal yang berhubungan dengan rumus matematis.

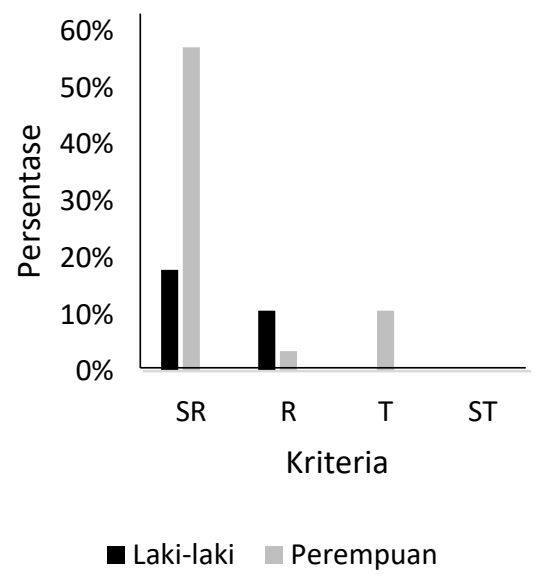

Gambar 3. Persentase Kemampuan Analisis Siswa

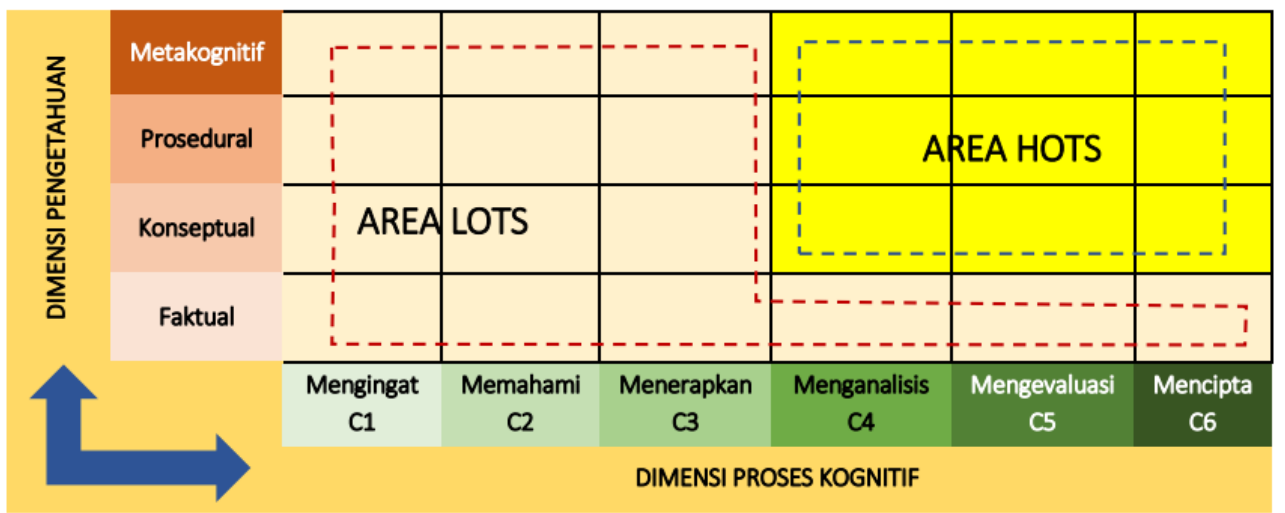

Gambar 4. Posisi Keterampilan Berpikir Tingkat Tinggi dalam Dimensi Proses Kognitif

Apabila kita menarik sebuah benda dengan kemiringan 370 terhadap arah horizontal. Jika gaya yang diberikan sebesar $100 \mathrm{~N}$, dan berhasil memindahkan benda sejaul 5 meter. Lukiskan peristiwa yang terjadi di atas beserta gaya yang bekerja pada benda tersebut sesuai dengan konsep fisika dan hitunglah besar usaha yang kita lakukan!

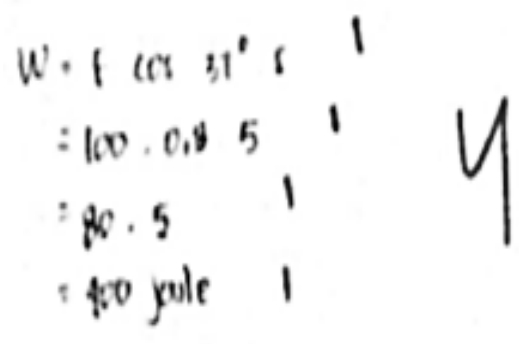

Gambar 5. Contoh Instrumen Soal dan Jawaban Kemampuan Analisis Siswa 
Instrumen yang terkait dengan kemampuan analisis (C4) dapat dikembangkan lebih luas dan ditingkatkan (Teodorescu et al., 2013). Pengembangan tersebut dapat dilakukan pada aspek indikator, jumlah soal, maupun pengembangan pada materi selain usaha dan energi.

Rendahnya kemampuan analisis siswa dapat disebabkan kesalahankesalahan dalam menjawab soal Rahmatina, et al., (2018). hasil kemampuan analisis siswa yang rendah juga ditemukan pada penelitian Nurazizah et al., (2017), yaitu sebesar $25 \%$.
Persentase Korelasi Minat Siswa Terhadap Kemampuan Analisis Siswa pada Konsep Usaha dan Energi

Tabel 2 menunjukkan korelasi minat terhadap kemampuan analisis siswa pada konsep usaha dan energi. Berdasarkan pola tersebut, terdapat korelasi antara dua variabel, yaitu minat dan kemampuan analisis siswa. Penelitian Naputri, Syarifuddin, \& Djulia (2016) menyatakan hal yang hampir sama, yaitu minat belajar memengaruhi kemampuan berpikir kritis siswa, yang termasuk dalam keterampilan berpikir tingkat tinggi (HOTS).

Tabel 2. Persentase Korelasi Minat Siswa Terhadap Kemampuan Analisis Siswa pada Konsep Usaha dan Energi

\begin{tabular}{ccccc}
\hline Kemampuan & \multicolumn{4}{c}{ Minat Siswa } \\
\cline { 2 - 5 } Analisis Siswa & $\begin{array}{c}\text { Sangat } \\
\text { Rendah } \\
(\%)\end{array}$ & $\begin{array}{c}\text { Rendah } \\
(\%)\end{array}$ & Tinggi (\%) & $\begin{array}{c}\text { Sangat } \\
\text { Tinggi (\%) }\end{array}$ \\
\hline Sangat Rendah (\%) & - & - & 67.86 & 7.14 \\
Rendah (\%) & - & - & 3.57 & 10.71 \\
Tinggi (\%) & - & - & 7.14 & 3.57 \\
Sangat Tinggi (\%) & - & - & - & - \\
\hline
\end{tabular}

Korelasi Antara Minat Siswa dan Keterampilan Analisis Siswa Berdasarkan Analisis SPSS IBM 23

Tabel 3 menunjukkan korelasi antara minat terhadap kemampuan analisis siswa. Analisis dilakukan menggunakan statistik non parametrik dengan SPSS IBM 23 menggunakan phi Cramer'sV. Approximate Significance atau yang biasa disebut $p$-value sebesar 0,000 < 0,05 , maka hipotesis diterima. Hasil tersebut membuktikan bahwa terdapat korelasi antara minat terhadap kemampuan analisis siswa pada konsep usaha dan energi. Korelasi juga dapat dilihat dengan menggunakan pola bahwa siswa dengan kemampuan analisis tertinggi memiliki minat yang tinggi. Hal ini menunjukkan 
pentingnya minat siswa dalam mengikuti pembelajaran. Siswa dengan minat belajar yang tinggi akan antusias dalam mengikuti pelajaran dan membuat penerimaan materi menjadi lebih mudah. Siswa dengan pemahaman materi yang baik akan lebih mudah melakukan analisis terhadap berbagai permasalahan terkait dengan konsep yang diajarkan.

Tabel 3. Korelasi antara Minat Siswa dan Kemampuan Analisis Siswa Berdasarkan Analisis SPSS IBM 23

\begin{tabular}{llrr}
\hline & Value & $\begin{array}{c}\text { Approximate } \\
\text { Significance }\end{array}$ \\
\hline Nominal by & Phi & 1.000 & .000 \\
Nominal & Cramer's V & 1.000 & .000 \\
N of Valid Cases & & 28 & \\
\hline
\end{tabular}

\section{KESIMPULAN}

Berdasarkan hasil penelitian ini dapat disimpulkan bahwa terdapat korelasi minat terhadap kemampuan analisis siswa pada konsep usaha dan energi. Korelasi dilihat dari perhitungan statistik non-parametrik yang diperoleh dari uji Phi Cramer's $V$ dengan nilai $p$ value sebesar $0,000 \quad(<0,5)$. Berdasarkan individu, siswa yang memiliki skor (kemampuan analisis) tinggi juga memiliki minat yang tinggi terhadap pembelajaran.

\section{DAFTAR PUSTAKA}

Ariyana, Y., Pudjiastuti, A., Bestary, R., Zamroni, Z., Mohandas, S. R., Kardiawarman, K., \& Lambas, L. 2018. Buku Pegangan Pembelajaran Berorientasi pada

Keterampilan Berpikir Tingkat Tinggi (Program Peningkatan
Kompetensi Pembelajaran Berbasis Zonasi). Direktorat Jenderal Guru dan Tenaga Kependidikan Kementerian Pendidikan dan Kebudayaan.

Astuti, S. P. 2015. Pengaruh Kemampuan Awal dan Minat Belajar terhadap Prestasi Belajar Fisika. Formatif: Jurnal Ilmiah Pendidikan MIPA, 5(1), 68-75.

https://doi.org/10.30998/format if.v5i1.167

Brigid Barron, B., \& Darlinghammond, L. 2008. Teaching for Meaningful learning A Review of Research on InquiryBased and Cooperative Learning (A Review of Research on Inquiry-Based and Cooperative Learning) ( $\mathrm{R}$. Furger, Ed.). Jossey-Bass. https://backend.edutopia.org/sit es/default/files/pdfs/edutopiateaching-for-meaningfullearning.pdf 
Djudin, T. 2018. How to Cultivate Students' Interests in Physics: A Challenge for Senior High School Teachers. Jurnal Pendidikan Sains, 6(1), 16-22. Gryczka, P., Klementowicz, E., Sharrock, C., \& Montclare, J. K. 2016. Interactive Online Physics Labs Increase High School Students' Interest. Journal of Technology and Science Education, 6(3), 166187.

https://doi.org/10.3926/jotse.19 1

Hasan, M., \& Jalil, Z. 2016. Penerapan Pemecahan Masalah Model Polya Untuk Meningkatkan Kemampuan Analisis Dan Hasil Belajar Pada Materi Vektor Di Sman 1 Darul Imarah. Jurnal Pendidikan Sains Indonesia, 4(1), 122221. https://doi.org/10.24815/jpsi.v4 i1.6593

Irawati, M. 2018. Profil Minat dan Hasil Belajar Siswa dalam Pembelajaran Matematika Kelas VIII SMP Negeri 5 Yogyakarta pada Pokok Bahasan Penyajian Data Dengan Menggunakan Aplikasi kahoot.

Jannah, S. W., Saptono, S., \& Lisdiana. 2018. Pengembangan Bahan Ajar Sistem Reproduksi Manusia Berwawasan Religi Sains Untuk Meningkatkan Kemampuan Analisis Siswa Ma. Prosiding Seminar Nasional Pendidikan Biologi, 177-185.
Kusuma, M. D., Rosidin, U., Abdurrahman, A., \& Suyatna, A. 2017. The Development of Higher Order Thinking Skill (Hots) Instrument Assessment In Physics Study. IOSR Journal of Research \& Method in Education (IOSRJRME), 07(01), 26-32. https://doi.org/10.9790/73880701052632

Najihah, A. R., Serevinan, V., \& Delina, M. 2018. The Development of High Order Thinking Skills (HOTS) Assessment Instrument for Temperature and Heat Learning. Jurnal Penelitian \& Pengembangan Pendidikan Fisika, 4(1), 19-26. https://doi.org/10.21009/1.041 03

Naputri, R. F., Syarifuddin, S., \& Djulia, E. 2016. Pengaruh Strategi Pembelajaran Berbasis Masalah dan Minat Belajar Terhadap Kemampuan Berpikir Kritis dan Hasil Belajar Siswa pada Materi Sistem Pencernaan Makanan Manusia di MAS Amaliyah Sunggal. Jurnal Pendidikan Biologi, 5(2), 119130.

https://doi.org/10.24114/jpb.v5 i2. 4308

Novita, S., Santosa, S., \& Rinanto, Y. 2016. The Comparison of Student Analitycal Thinking Between the Implementation of Cooperative Learning and Guided Discovery Learning Model. Proceeding Biology 
Education Conference, 13(1), 359-367.

Nurazizah, S., Sinaga, P., \& Jauhari, A. 2017. Profil Kemampuan Kognitif dan Keterampilan Berpikir Kritis Siswa SMA pada Materi Usaha dan Energi. Jurnal Penelitian \& Pengembangan Pendidikan Fisika, 3(2), 197-202. https://doi.org/10.21009/1.032 11

Oktalia, Y., Sakti, I., \& Hamdani, D. 2017. Pengaruh Minat Dan Motivasi Pada Penerapan Model Diskoveri Berbantuan Media Animasi Terhadap Hasil Belajar Fisika Di Sma Negeri 4 Kota Bengkulu. Jurnal Ilmu Dan Pembelajaran Fisika, 1(1), 87-95.

https://ejournal.unib.ac.id/inde x.php/jipf/article/view/3464/0

Oon, P. T., \& Subramaniam, R. 2013. Factors influencing Singapore students' choice of physics as a tertiary field of study: A Rasch analysis. International Journal of Science Education, 35(1), 86118.

https://doi.org/10.1080/095006 93.2012.718098

Qomariya, Y., Muharrami, L. K., \& Hadi, W. P. 2018. Profil Kemampuan Berpikir Analisis Siswa SMP Negeri 3 Bangkalan dengan Menggunakan Metode Pictorial Riddle dalam Pembelajaran Inkuiri Terbimbing. Journal of Natural
Science Education Reseach, 2015, 9-18.

Rahmatina, D. I., Sutopo, \& Wartono. 2018. Identifikasi Kesulitan Siswa SMA pada Materi Usaha-Energi. Momentum: Physics Education Journal, 2(1), 15. https://doi.org/10.21067/mpej. v2i1.2370

Refiana, R., Jamal, M. A., \& Hartini, S. 2016. Meningkatkan Kemampuan Analisis Siswa Kelas X MS3 SMAN 2 Banjarmasin Pada Materi Gerak Melingkar Melalui Pengajaran Langsung Bermetode Pemecahan Masalah. Berkala Ilmiah Pendidikan Fisika, 4(1), 64.

https://doi.org/10.20527/bipf.v $4 \mathrm{i} 1.1048$

Riwahyudin, A. 2015. Pengaruh Sikap Siswa Dan Minat Belajar Siswa Terhadap Hasil Belajar Ipa Siswa Kelas V Sekolah Dasar Di Kabupaten Lamandau. Jurnal Pendidikan Dasar, 6(1), 11. https://doi.org/10.21009/jpd.06 1.02

Salsabila, N. H., \& Setyaningrum, W. 2018. Game "STATIC": Is It Interesting for Students? Journal of Physics: Conference Series, 1097(1), 1-8. https://doi.org/10.1088/17426596/1097/1/012105

Sartono, N., Rusdi, H. R. 2017. Pengaruh Pembelajaran Process Oriented Guided Inquiry Learning (POGIL) dan 
Discovery Learning Terhadap Kemampuan Berpikir Analisis Siswa SMAN 27 Jakarta pada Materi Sistem Imun. Biosfer: Jurnal Pendidikan Biologi(Biosferjpb), 10(1), 5864.

Septa Pratama, N., \& Istiyono, E. 2015. Studi Pelaksanaan Pembelajaran Fisika Berbasis Higher Order thinking (HOTS) Pada Kelas X Di SMA Negeri Kota Yogyakarta. Prosiding Seminar Nasional Fisika Dan Pendidikan Fisika (SNFPF), 6, 6.

Suryani, L., Saputro, A., \& Martini, K. 2015. Implementasi Model Pembelajaran Problem Posing Dilengkapi Lks Untuk Meningkatkan Kemampuan Analisis Dan Prestasi Belajar Materi Konsep Mol Siswa Kelas X Sma N 8 Surakarta Tahun Pelajaran 2013/2014. Jurnal Pendidikan Kimia
Universitas Sebelas Maret, 4(4), 186-192.

Teodorescu, R. E., Bennhold, C., Feldman, G., \& Medsker, L. 2013. New approach to analyzing physics problems: A taxonomy of introductory physics problems. Physical Review Special Topics - Physics Education Research, 9(1), 120.

https://doi.org/10.1103/PhysRe vSTPER.9.010103

Tohir, M. 2019. Hasil PISA Indonesia Tahun 2018 Turun Dibanding Tahun 2015. 20182019.

https://doi.org/10.31219/osf.io/ pcjvx

Winarti, W. 2015. Profil Kemampuan Berpikir Analisis Dan Evaluasi Mahasiswadalam Mengerjakan Soal Konsep Kalor. Jurnal Inovasi Dan Pembelajaran Fisika, 2(1), 1924. 